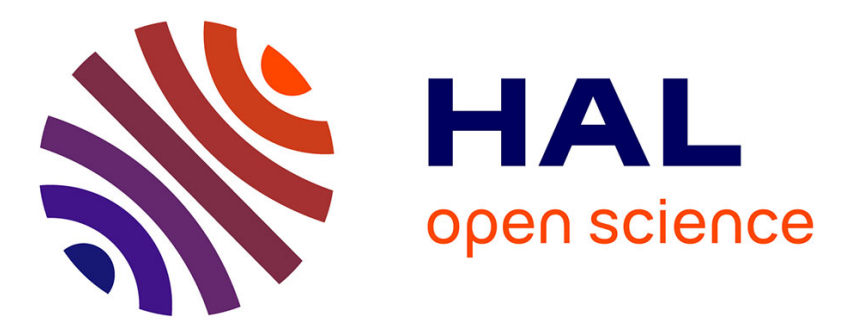

\title{
Large-scale geographic patterns of mercury contamination in Morocco revealed by freshwater turtles
}

Tahar Slimani, Mohamed Said El Hassani, El Hassan El Mouden, Marine

Bonnet, Paco Bustamante, Francois Brischoux, Maud Brault-Favrou, Xavier

Bonnet

\section{To cite this version:}

Tahar Slimani, Mohamed Said El Hassani, El Hassan El Mouden, Marine Bonnet, Paco Bustamante, et al.. Large-scale geographic patterns of mercury contamination in Morocco revealed by freshwater turtles. Environmental Science and Pollution Research, 2018, 25 (3), pp.2350-2360. 10.1007/s11356017-0643-5 . hal-01634574

\section{HAL Id: hal-01634574 \\ https://hal.science/hal-01634574}

Submitted on 3 Mar 2019

HAL is a multi-disciplinary open access archive for the deposit and dissemination of scientific research documents, whether they are published or not. The documents may come from teaching and research institutions in France or abroad, or from public or private research centers.
L'archive ouverte pluridisciplinaire HAL, est destinée au dépôt et à la diffusion de documents scientifiques de niveau recherche, publiés ou non, émanant des établissements d'enseignement et de recherche français ou étrangers, des laboratoires publics ou privés. 


\section{Large-scale geographic patterns of mercury contamination in Morocco revealed by freshwater turtles}

Slimani T. 1, El Hassani M.S. 1, El Mouden E.H. 1, Bonnet M. 2, Bustamante P. 3 ,

Brischoux F. ${ }^{2}$, Brault-Favrou M. ${ }^{3}$, Bonnet X. ${ }^{2}$

1. Cadi Ayyad University Faculty of Sciences Semlalia, Laboratory Biodiversity and Ecosystem Dynamics, P.O. Box 2390, Marrakesh 40000, Morroco

2. Centre d'Etude Biologique de Chizé, UMR 7372, CNRS - Université de La Rochelle, 79360 Villiers en Bois, France

3. Littoral Environnement et Sociétés (LIENSs), UMR 7266 CNRS-Université de la Rochelle, 2 rue Olympe de Gouges, 17000 La Rochelle, France

Corresponding author: X Bonnet, bonnet@cebc.cnrs.fr 


\begin{abstract}
Mercury $(\mathrm{Hg})$ is a toxic contaminant present in most aquatic ecosystems. High concentrations pose serious threats to organisms and to human health. Because previous studies focused on few countries, environmental hazard due to $\mathrm{Hg}$ contamination remains obscure in many geographic areas, and for example limited information is available in North Africa. We examined total $\mathrm{Hg}$ contamination in 13 sites in Morocco (12 rivers and one lake) spread over a large area, $400 \mathrm{~km}$ northsouth and $350 \mathrm{~km}$ west-east, that encompasses different biogeographic zones separated by the Atlas Mountains. Due to their longevity and sedentary habits, we used freshwater turtles as biological probes to monitor $\mathrm{Hg}$ exposure. Keratinized tissues reflect long-term $\mathrm{Hg}$ exposure; thus, we assayed $\mathrm{Hg}$ concentration in the claws of $>200$ individuals and supplemented these data with blood $\mathrm{Hg}$ concentrations of $>60$ individuals (a tissue that provides shorter term $\mathrm{Hg}$ exposure integration). The results provide the first largescale picture of $\mathrm{Hg}$ contamination in the aquatic freshwater systems of Morocco. Comparisons with previous studies revealed that some of the sites were highly contaminated (e.g. mean $\mathrm{Hg}$ concentrations were above $5 \mu \mathrm{g} \mathrm{g}^{-1}$, a very high level in keratinized tissues) whereas other sites presented moderate or baseline levels. Unexpectedly, all highly contaminated sites were found in less densely populated areas, while more densely urbanized northern sites, even the sewers of large cities, were not highly contaminated. We hypothesize that silver mining activities in the southern High Atlas and in the Anti-Atlas contaminate rivers of the catchment basins over long distances. These findings indicate that fish, water consumption and contamination levels in local people should be further scrutinized
\end{abstract}

Keywords: bio-monitoring, chelonian, $\mathrm{Hg}$, keratinized tissues, Mauremys, rivers 


\section{Introduction}

Mercury $(\mathrm{Hg})$ is a widespread contaminant that originates from various natural and anthropogenic sources (Mason et al. 1994; Selin 2009). It can be transported by atmospheric and water fluxes and it tends to concentrate in aquatic ecosystems, sometimes creating reservoirs that can release considerable amounts of $\mathrm{Hg}$ into the environment (Morel et al. 1998; Mason \& Sheu 2002). Hg is a toxic element that circulates rapidly across trophic levels, accumulates in animal tissues, and reaches deleterious concentrations especially in predators, including humans (Jernelöv \& Lann 1971; Aschner \& Aschner 1990; Boening 2000; Bernhoft 2011; Driscoll et al. 2013). Complex physico-chemical and biochemical processes are involved in the global fluxes of $\mathrm{Hg}$ across ecosystems and organisms, including air transport (e.g. $\mathrm{Hg}$ vapor $\mathrm{Hg} 0$ ), precipitation, deposition, transformation (e.g. $\mathrm{Hg}$ is methylated by microorganisms to form methyl-Hg), as well as various degrees of assimilation and accumulation by plants and animals (Miller et al. 2005). Although it is important to study the whole process in order to precisely track $\mathrm{Hg}$ and accurately address environmental and health issues, comprehensive assessment of $\mathrm{Hg}$ contamination in entire trophic webs is often logistically unfeasible. Consequently, vast geographic regions have been insufficiently investigated or not monitored at all. In this broad context, identifying reference organisms and using simple sampling techniques is a useful approach for large scale tracking of $\mathrm{Hg}$ accumulation in water ecosystem.

In North Africa, broad scale estimates of atmospheric Hg deposits suggest that such contamination represents a potential environmental threat (Pirrone et al. 2001; Pacyna et al. 2010). Yet, few local-scale studies are available, they provided contrasting results. In an Algerian site, elevated groundwater $\mathrm{Hg}$ concentrations 
have been reported and associated with worrying contamination levels of schoolchildren (Benhamza \& Hammar 2012). In Morocco, low concentrations of Hg were found in commercialized fish and cephalopods (Chahid et al. 2014) and in humans that regularly consume these animals (Elhamri et al. 2007); but relatively high levels were detected in the Mediterranean mussel Mytilus galloprovincialis (Maanan 2007). Another study documented high metal contamination of a river mouth in a densely populated area, but confusing effects of the tide and water currents generated complex and fluctuating patterns (Bennasser et al. 1999). Overall, to the best of our knowledge, published information regarding $\mathrm{Hg}$ concentrations of the environment in North Africa is restricted to a small number of sites and is partly blurred by ambivalent results and by the impact of confusing factors. Improving our knowledge is important for mapping the relative risk due to $\mathrm{Hg}$ contamination at large scale, especially in continental aquatic ecosystems where $\mathrm{Hg}$ tends to bioaccumulate in its most toxic form, i.e. methyl-Hg. Because substantial spatial and temporal variations of $\mathrm{Hg}$ water contamination further complicate assessments (Bindler et al. 2004; Selin \& Jacob 2008), reference values collected over a large spatial scale are needed.

In this study, freshwater turtles were used as bioindicators to monitor $\mathrm{Hg}$ contamination across a wide geographic gradient in Morocco, ranging from semiarid Mediterranean to highly arid sub-Saharan climatic zones. The gradient encompasses rivers situated in the plains of northern Morocco to the southern part of the Atlas Mountains. It also includes both highly urbanized and sparsely populated rural areas. Despite the complexity of the processes governing trace metal 
accumulation, $\mathrm{Hg}$ contamination generally tends to increase in urban and industrialized areas compared to rural areas (Rutter et al. 2008; Wei and Yang 2010; Azimi and Moghaddam 2013). Thus, rivers crossing large cities should be more contaminated compared to those running from the foothills of the Atlas in rural areas with low population density.

Freshwater turtles are useful biological probes for tracking $\mathrm{Hg}$ in the aquatic environment (Bergeron et al. 2007; Hopkins et al. 2013a; Schneider et al. 2015). They feed on relatively high trophic levels and exhibit a high somatic conversion rate of the food: two features that explain their ability to integrate long-term $\mathrm{Hg}$ exposure into their tissues that express a slow turn over (e.g. dermis, bones). The most toxic form of $\mathrm{Hg}, \mathrm{MeHg}$, tends to bioaccumulate and to bind to keratin and hence is expected to be deposited in the keratin rich claws. Precisely, $\mathrm{Hg}$ concentrations recorded in the keratinized tissues of turtles offer a reliable way to monitor long-term $\mathrm{Hg}$ accumulation caused by environmental exposure in contaminated areas (Hopkins et al. 2013a). In contrast, monitoring $\mathrm{Hg}$ concentrations directly in waters and sediments is challenging due to the strong temporal fluctuations caused by events such as flooding and highly variable flow rates. Precisely Moroccan rivers are subjected to extremely strong flooding events (Zielhofer et al. 2010; Tramblay et al. 2012). Terrestrial and freshwater chelonians are long-lived organisms with limited capacity for long-distance migrations. Most individuals are philopatric and have a small home range in comparison to other widely sampled vertebrates (e.g. birds and mammals). The contamination levels of their tissues should reflect their local environment while migrating or wandering animals can be contaminated far from 
the place where they have been sampled. Therefore, sedentary species like turtles provide relatively spatially accurate information. Many freshwater turtles are easy to catch, tolerant to manipulation and they are abundant in many aquatic ecosystems. Their claws provide suitable keratinized tissues for assays, allowing nonlethal monitoring of $\mathrm{Hg}$ concentrations (Hopkins et al. 2013a; Schneider et al. 2015). In addition, blood can be easily retrieved via venipuncture; this provides a complementary tissue to assess short-term (e.g. days, weeks) exposure to $\mathrm{Hg}$ contamination (Hopkins et al. 2013a). Freshwater turtles are characterized by indeterminate growth (growth continues after sexual maturity), they display strong variations of growth trajectories and thus many populations contain a wide range of juvenile and adult body sizes (Rhen and Lang 1995). Most studies showed a positive relationship between body mass and $\mathrm{Hg}$ contamination, older and larger individuals accumulating contaminants over time (Meyers-Schöne et al. 1993; Bergeron et al. 2007). Overall, freshwater turtles display a unique set of features that allow the surveillance of $\mathrm{Hg}$ in aquatic systems using cost-effective and minimally invasive field procedures.

We sampled more than 200 individuals of Mediterranean turtles (Mauremys leprosa), a freshwater species locally abundant and widely distributed over a very large area in the western Mediterranean region. Using non-destructive techniques, we collected blood and cut the tip of claws in order to assay $\mathrm{Hg}$ concentrations in these two tissues. Overall, we sampled 12 rivers and one artificial lake. Our main objectives were twofold. Firstly, we examined if the claws and the blood of a previously untested chelonian species in a previously untested area were effectively 
contaminated by Hg. This methodological objective aimed to test if M. leprosa can be used as a possible biological probe across its vast distribution range around Mediterranean areas and in North Africa. Secondly, providing that the first objective was fulfilled, we intended to perform the first large-scale assessment of $\mathrm{Hg}$ contamination of Morocco using a uniform methodology. Indeed, continental waters of the Maghreb region are seriously threatened by climatic changes (Schilling et al. 2012). They are overexploited and polluted to supply agricultural, industrial and touristic activities. Preserving water resources in Morocco is urgent and of paramount importance. Thus, assessing $\mathrm{Hg}$ concentrations, one of the most widespread water pollutants, represents a key environmental and health issue.

In practice, we addressed three main successive questions:

1) Do Mediterranean turtles exhibit significant $\mathrm{Hg}$ concentrations in their claws and in their blood as observed in several other species?

2) Is there a significant relationship between body mass and $\mathrm{Hg}$ concentration levels?

3) Are $\mathrm{Hg}$ burdens related to the putative sources of $\mathrm{Hg}$ in a broad geographical context? For example, are Hg concentrations measured in turtles proportional to the density of industrial or municipal sources across Morocco?

\section{Material and methods}

\section{Study sites}

From 2012 to 2016, we sampled 13 aquatic sites (12 rivers and 1 lake) spread across a wide area of Morocco (Table 1; supplementary material Table A; Fig. 1), 400 km 
north-south versus $\sim 350 \mathrm{~km}$ west-east that includes very large and small cities, i.e.

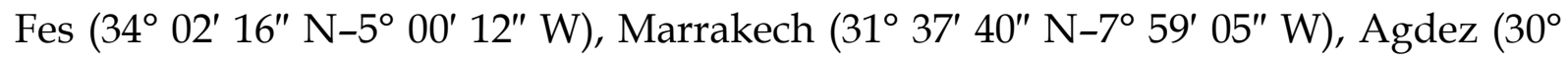

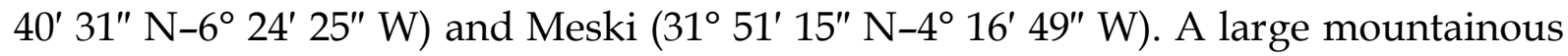
formation represented by the High Atlas (> 4100 altitude max) and the Middle Atlas (> 3350 altitude max) divides the study area into four major biogeographical zones. A typical Mediterranean semi-arid climate occurs in the plains of the most northern sites (e.g. Moulay Driss site). A more arid and hot climate prevails in the north foothills of the High Atlas (e.g. Marrakech site). A sub-Saharan arid and hot climate characterize the sites situated in the southern parts (e.g. Ouarzazate, Agdez), and a semi-arid continental (cold in winter and hot in summer) climate occurs in the area between the High Atlas and the Middle Atlas (Zaïda site). Importantly, the main mountain chains separated major large catchment basins. For instance, the rivers sampled at the sites 1, 2 and 3 belong to the same aquatic system; similarly, the river sampled at the site 5 is an affluent of the river of the site 6 . The rivers sampled at the sites 9, 10 and 13 converge to the lake (site 12) which in turn supplies the river sampled at the site 11 . Therefore, the 13 sites sampled could be assigned to three main geographic areas (Fig. 1): rivers running from the North slopes of the Atlas (sites 1-6), rivers running from the region situated between the High Atlas and the Middle Atlas toward the east (sites 7 and 8) and rivers (+ one lake) running from the south slopes of the High Atlas toward the west and/or the south (sites 9-13). In analysis, we considered these three main catchment basins rather than the four major biogeographical zones. 
Within these main catchment basins, we sampled a variety of sites, considering the origin of each river, flow rate, continuity of the aquatic system and degree of anthropogenic pressure. Some sampling sites were situated upstream or downstream of cities with highly variable population sizes, from less than 1000 people to more than one million inhabitants (supplementary material Table A). Several rivers are interrupted most of the year, except during infrequent flooding events. Several sites were situated at the sewers of the cities (e.g. Fes), while other rivers ran directly from the mountains without crossing any urbanized area except very small villages (e.g. Ouaoumana) (Table 1; supplementary material Table A).

\section{Study species}

We captured, by hand or using traps baited with fish and/or meat, 262 individuals of the Mediterranean turtle Mauremys leprosa. This species is widespread in Morocco and it often occurs in large numbers. This turtle inhabits various types of freshwater and brackish water bodies and rivers (Meek 1987). It is a medium size chelonian; females being larger than males (Bonnet et al. 2010). In Spain, body size (straight shell length) ranges approximately between 25 and $95 \mathrm{~mm}$ in juveniles; the mean body size is $165 \mathrm{~mm}(\max 205 \mathrm{~mm})$ and $145 \mathrm{~mm}(\max 175 \mathrm{~mm})$ respectively in females and males (Muñoz and Nicolau 2006). Measurements recorded in the Moroccan population studied suggest that individuals are slightly larger; the smallest turtles was $34 \mathrm{~mm}$ long, the mean body size was $169 \mathrm{~mm}$ (max $257 \mathrm{~mm}$ ) and $154 \mathrm{~mm}(\max 203 \mathrm{~mm}$ ) respectively in females and in males (Bonnet et al. 2016). In most individuals ( $>80 \%, N=211)$, following capture we cut off the extremity of 3 to 
5 claws per turtle and kept the samples in Eppendorf tubes filled up with 100\% ethanol. We also blood sampled approximately $30 \%$ of the individuals $(\mathrm{N}=66)$ and retrieved 0.1 to $0.9 \mathrm{ml}$ of blood (see Bonnet et al. 2016 for puncture details). The blood was immediately centrifuged (at 10,000×g for $3 \mathrm{~min}$ ) to separate plasma from blood cells (essentially erythrocytes; hereafter referred as 'RBC' for red blood cells). Absolute ethanol was then added to RBC for preservation. We recorded sex, body size (straight shell length, SSL with a calliper) and body mass $( \pm 1 \mathrm{~g}$ measured with an electronic scale). Body condition was expressed as log-body mass scaled by logbody size (Bonnet et al. 2001). It is an integrative index of the health and trophic status of individuals that accounts for body reserves (lipidic, proteic, glucid reserves), gut content and clutch mass notably (Bonnet et al. 2010). Individual body condition was calculated as the residual value from the linear regression of body size length against body mass (Bonnet et al. 2001). Each turtle was permanently marked (shell notches) and rapidly released at the site of capture.

Two subspecies of the Mediterranean turtle have been identified, M. l. leprosa and Mauremys leprosa saharica. The ridge of the High Atlas separates their respective distribution range (M. l. leprosa in the north and M. l. saharica in the south; Fritz et al. 2006). Only M. l. saharica occurs in the southern sites sampled (sites 7 to 13; Fig. 1). In this subspecies, individuals were either moderately or highly contaminated (see the Results section). Thus, the geographical differences in contamination levels we observed were not blurred by this taxonomic issue.

\section{Mercury analysis}


Total $\mathrm{Hg}$ concentration measurements were performed on dried tissue aliquots ranging from 2 to $10 \mathrm{mg}$ using an Advanced Mercury Analyzer (AMA-254, Altec) as described in Blévin et al. 2013. The analytical process consists of a drying period prior to a combustion phase at $750{ }^{\circ} \mathrm{C}$ which leads to the release of $\mathrm{Hg}$ from the samples. Subsequently, the $\mathrm{Hg}$ vapor produced is carried by an oxygen flow to a gold amalgamator and trapped on its surface. Thereafter, the collected $\mathrm{Hg}$ is liberated from the amalgamator by a short heat-up and then detected by atomic absorption spectrophotometry.

All analyses were repeated two to three times until reaching a relative standard deviation below 5\%. Accuracy was checked using TORT-2 Lobster Hepatopancreas (NRC, Canada) as certified reference material $\left(0.27 \pm 0.06 \mu \mathrm{g} \mathrm{g}^{-1} \mathrm{dwt}\right)$, and results were in good agreement with the certified values $\left(0.24 \pm 0.04 \mu \mathrm{g} \mathrm{g}^{-1} \mathrm{dwt}, \mathrm{N}=6\right)$. Blanks (control samples) were analysed at the beginning of each set of samples and the detection limit of the method was $0.05 \mathrm{ng}$. All $\mathrm{Hg}$ concentrations are expressed as micrograms per gram dry weight $(\mathrm{dw})$.

\section{$\underline{\text { Statistical analyses }}$}

Not all measurements were recorded on each individual and it was often impossible to determine the sex of small individuals. Therefore, sample size varied from 66 for Hg concentration assayed in the RBC, to 213 for claw sampling, and to 262 for SSL. In several individuals, sampling was incomplete (e.g. two body masses not available), generating modest fluctuations in the final sample size used for analyses. 
The relationship between the $\mathrm{Hg}$ concentrations respectively assayed in the claws and in the RBC was assessed using a linear regression on 34 individuals where both tissues were analysed. In this subsample, the normal probability plot of the residuals (that exhibited a normal distribution) was approximately linear. This indicates that the error terms were normally distributed in this analysis. Further, a careful inspection of the data set revealed that it was free from outliers (see the Results section).

The other analyses were based on larger sample sizes (e.g. $\mathrm{N}=211$ claw samples), and small individuals were included. The dependent variables were not normally distributed; they were generally skewed toward low values (especially $\mathrm{Hg}$ concentrations) or toward high values (SSL), even after log or Box-Cox transformations (all Shapiro-Wilk $\mathrm{W}<0.975, \mathrm{P}<0.001$ ); nonetheless, the seconds provided distribution close to normality. Therefore, the effect of geographic sites (the main issue addressed) on contamination levels was modelled with a Poisson distribution of untransformed $\mathrm{Hg}$ values and a log link in a generalized linear model (GLM); dispersion parameter was estimated by Pearson's chi-square statistic divided by its degrees of freedom. Analyses were performed again using Box-Cox transformed concentrations and none of the outcome was significantly changed (e.g. for the correlation between $\mathrm{Hg}$ concentrations measured in the RBC and in the claws $\mathrm{r}=0.92$ and $\mathrm{r}=0.94$ using respectively untransformed and Box-Cox transformed data; nonparametric tests were not affected). In addition to site (the main factor), sex (categorical factor) and body mass (continuous covariate) were implemented in the analyses because these factors can influence contamination levels in some turtle 
species (Meyers-Schöne et al. 1993; Bergeron et al. 2007) albeit not in others (Hopkins et al. 2013b). Body size and body mass were highly correlated $(\mathrm{R} 2=0.98, \mathrm{~F} 1,258=$ 10,986, P < 0.001). Each individual was represented only once. Analyses were performed with STATISTICA.12 (StatSoft France 2013, www.statsoft.fr.)

\section{Results}

Hg concentrations varied across a wide range of values, from 0.030 to $13.956 \mu \mathrm{g} \mathrm{g}^{-1}$ in the claws (mean $1.756 \pm 2.308 \mu \mathrm{g} \mathrm{g}^{-1}, \mathrm{n}=211$ ) and from 0.011 to $2.114 \mu \mathrm{g} \mathrm{g}^{-1}$ in the RBC (mean $0.260 \pm 0.394 \mu g \mathrm{~g}^{-1}, \mathrm{n}=66$ ). This wide spectrum of variation among individuals shows that in certain cases, the targeted tissues were able to concentrate appreciable amounts of $\mathrm{Hg}$ in $\mathrm{M}$. leprosa.

\section{Comparison between RBC and claw $\mathrm{Hg}$ concentrations}

The Hg concentrations measured in the RBC and in the claws were highly correlated $(\mathrm{r}=0.92, \mathrm{~F} 1,32=187.67, \mathrm{P}<0.001, \mathrm{~N}=34$ individuals with both $\mathrm{RBC}$ and claws sampled, Fig. 2). The values recorded in the claws were significantly higher (Wilcoxon test for paired samples, $\mathrm{Z}=5.069, \mathrm{P}<0.001$ ).

\section{$\underline{\text { Relationship between body mass and } \mathrm{Hg} \text { concentrations }}$}

We found significant negative correlations between body mass and $\mathrm{Hg}$ concentrations measured in the claws $(\mathrm{r}=-0.33, \mathrm{~F} 1,207=25.71, \mathrm{P}<0.001, \mathrm{~N}=209)$ and in the RBC ( $\mathrm{r}=-0.75, \mathrm{~F} 1,56=75.41, \mathrm{P}<0.001, \mathrm{~N}=58)$ (Fig. 3). A small proportion of the variance was explained in the first correlation $\left(\mathrm{R}^{2}=11 \%\right)$, but this 
proportion was elevated in the second $\left(\mathrm{R}^{2}=56 \%\right)$. Considering each of the three main catchment basins separately, negative correlations were found only in the turtles sampled in the south slope rivers $(\mathrm{r}=-0.433, \mathrm{P}<0.001$ and $\mathrm{r}=-0.611, \mathrm{P}<0.002$ for $\mathrm{Hg}$ concentrations measured in the claws and in the $\mathrm{RBC}$, respectively); in the two other basins, we found no significant correlation (Fig. 3).

A stepwise backward multiple regression suggested that the body condition of the individuals was best explained when the $\mathrm{Hg}$ contamination level was taken into account (Table 2). Indeed, the model was slightly, albeit significantly, improved when $\mathrm{Hg}$ concentration was included in addition to body size (straight shell length, SSL). Importantly, the coefficient for $\mathrm{Hg}$ concentrations was negative (Table 2).

\section{Geographic differences}

The mean body size of the turtles varied among sites (ANOVA using SSL as the dependent variable, F12, $198=5.325, \mathrm{P}<0.001$ or using BM, F12, $196=5.065, \mathrm{P}<$ 0.001). Therefore, we considered body mass (BM) in subsequent analyses. The $\mathrm{Hg}$ concentrations measured in the claws differed markedly among the aquatic sites sampled (Table 3; Figs. 3 and 4a). As sex has no significant effect on $\mathrm{Hg}$ concentrations, analyses were performed again without this factor; this allowed us to include 15 small unsexed individuals (Table 3). Because the effect of body mass was significant, we also presented mean values adjusted to body mass (Fig. 4b). The site main effect remained very strong (Table 3), with significant differences among most sites (Table 4). Considering the three main catchment basins, a GLM analysis revealed strong effects on $\mathrm{Hg}$ concentrations in claws (see grey patterns in Fig. 3 and 
Table 5). The minimal $\mathrm{Hg}$ concentration (an index of the background level) varied among these three main areas: $0.03,0.24$ and $0.78 \mu \mathrm{g} \mathrm{g}^{-1}$ respectively in the north-, east- and south-oriented slopes of the mountains.

The smaller sample size based on RBC did not include the two sites situated in the most eastern part of the studied geographic area (i.e. Zaïda and Meski). It was nonetheless possible to compare the rivers downstream of the North versus South slopes of the Atlas. We found a strong differences between these broad areas (Kruskal-Wallis test, $\mathrm{H} 1=42.862, \mathrm{P}<0.001, \mathrm{~N}=66$ ). The mean values were $0.052 \pm$ $0.042 \mu \mathrm{gg}^{-1}(\mathrm{~N}=43)$ in the north and in the south and $0.650 \pm 0.057 \mu \mathrm{g} \mathrm{g}^{-1}(\mathrm{~N}=23)$, and thus, they were approximately one order of magnitude higher in the southern aquatic systems.

\section{Discussion}

The current survey performed over a large geographic scale on a large sample size of Mediterranean turtles revealed very strong differences of $\mathrm{Hg}$ contamination across the freshwater systems of Morocco. The mean concentrations recorded suggest that some sites were highly contaminated whereas others presented moderate or low contamination levels. The variation across sites was not random. Instead, all the sites sampled that are supplied by waters running from the south slopes of the High Atlas were highly contaminated whereas contamination remained moderate or low in the other sites. Below we discuss methodological issues regarding the use of freshwater turtles to investigate $\mathrm{Hg}$ contamination in the environment; next, we consider the strong contrasts observed among the sites. 


\section{Comparison with published data}

The scientific literature regarding $\mathrm{Hg}$ contamination in reptiles, including non-avian and avian taxa, provides abundant data and thus robust references (Wayland et al. 2003; Burger and Gochfeld 2004; Turnquist et al. 2011; Schneider et al. 2013, 2015). In a recent review Schneider et al. (2013) summarized, almost all assessments of $\mathrm{Hg}$ concentrations recorded in keratinized tissues including 23 chelonian species $(\mathrm{N}>29$ mean values). The average mean value was $0.717 \pm 0.858 \mu \mathrm{g} \mathrm{g}^{-1}$ with a $95 \% \mathrm{CI}$ of 0.681 to 1.161 , a median of 0.324 and extreme values ranging from 0.002 to 2.851 (derived from the Table 1 in Schneider et al. 2013, one extreme outlier excluded). The mean values we observed in the south-eastern sites were all above $2 \mu \mathrm{g} \mathrm{g}-1$ and reached mean values above $5.5 \mu \mathrm{g} \mathrm{g}^{-1}$ (Fig. 3). A recent study (Hopkins et al. 2013b) carried out in different sites upstream and downstream of a highly polluted spot in the Holston River (USA) offers a straightforward comparison with the 13 sites we investigated: moderate $\mathrm{Hg}$ concentrations were observed in three turtle species living upstream of a former chloralkali plant, but $\mathrm{Hg}$ concentrations rose to very high values immediately downstream of the contamination source, and remained elevated more than $100 \mathrm{~km}$ downstream. Our results are relatively close regarding the range of mean concentrations across sites $\left(0.196 \pm 0.490\right.$ to $5.887 \pm 3.352 \mu \mathrm{g} \mathrm{g}^{-1}$ in Morocco versus $2.464 \pm 0.339$ to $\sim 21.000 \mu \mathrm{g} \mathrm{g}^{-1}$ in the Holston River) and considering maximal values (13.956 in Morocco versus $42.250 \mu \mathrm{g} \mathrm{g}^{-1}$ in the Holston River). Overall, the high concentrations we found are closer to those recorded in a river classified as highly polluted in the USA (Hopkins et al. 2013b) compared to other systems investigated (Schneider et al. 2013, 2015). In seabirds that are considered as major 
sentinels of marine environments, $\mathrm{Hg}$ concentrations recorded in feathers (a keratinized tissue) above a mean value of $2 \mu \mathrm{g} \mathrm{g}^{-1}$ induce deleterious population effects (Goutte et al. 2014). In general, a mean value of $5 \mu \mathrm{g} \mathrm{g}^{-1}$ is considered as a threshold above which negative effects are expected in birds (Eisler 1987; Fig. 5 in Burger and Gochfeld 2004). Thus, our data clearly reveal high contamination levels specifically in the aquatic systems downstream of the south slopes of the High Atlas (yet the proportion of methyl-Hg should be investigated for a more accurate assessment; Blanvillain et al. 2007).

\section{Usefulness of M. leprosa to track $\mathrm{Hg}$ contamination}

Rivers are rapidly changing systems, especially in arid countries like Morocco where sudden flooding events can quickly strip sediments, reshape banks and modify the delimitation of the main and secondary beds (Zielhofer et al. 2010). In this everchanging context, assessing chronic environmental exposure to contaminants can be particularly difficult. Long-lived sedentary organisms that can be sampled individually offer a valuable way to circumvent this difficulty and to integrate temporal variations of $\mathrm{Hg}$ exposure, providing that they accumulate and retain $\mathrm{Hg}$ in their tissues. Our results precisely show that M. leprosa fulfils this criterion. Such capacity of accumulation is particularly valuable in the context of rapid and seasonal changes of water flows combined with possible time variations of $\mathrm{Hg}$ release from the sources toward rivers.

Hg shows an affinity for keratinized tissues due to their high sulphur content. Thus, $\mathrm{Hg}$ tends to accumulate in the claws of reptiles. Sampling this tissue is particularly 
useful because the tip of the claws can be easily taken without damaging individuals (Hopkins et al. 2013a; Schneider et al. 2015). The wide range of variation of $\mathrm{Hg}$ concentrations among individuals with the elevated maximal values we found in this study revealed that $M$. leprosa is an appropriate species to monitor $\mathrm{Hg}$. The strong correlation we found between $\mathrm{Hg}$ concentrations measured in claws and RBC, with higher concentrations in the former, has been previously documented in other species (Hopkins et al. 2013b; Schneider et al. 2013). The most accurate contamination signal to survey a polluted river was obtained from claws due to their higher accumulating potential (Hopkins et al. 2013a). However, the differences we observed between claw and RBC concentrations in the most contaminated catchment basin, along with the strong negative relationship between body mass and $\mathrm{RBC} \mathrm{Hg}$ concentrations (this relationship was weaker with claws), suggest that these tissues offer complementary measures for $\mathrm{Hg}$ exposure (Fig. 3). Claws grow slowly and provide long-term accumulation assessment while relatively rapidly renewed blood cells rather reflects short-term exposure and likely provides more dynamic results. The steep and strong negative correlation between body mass and $\mathrm{Hg}$ concentration is likely associated to an ontogenic shift in foraging ecology. This relationship can be used as a correcting factor to calibrate environmental monitoring of Hg exposure, at least in areas where $\mathrm{Hg}$ contamination is substantial.

\section{$\underline{\text { Large-scale geographic variations }}$}

Our most salient results regarding $\mathrm{Hg}$ concentrations were the clear geographical pattern and the negative effect of body mass (Table 4; Fig. 3). The significant 
influence of body mass on $\mathrm{Hg}$ concentrations was negative, but significant only in the most contaminated area and thus of secondary importance compared to the dominant effect of site. Exploring underlying physiological or behavioural mechanisms that explain why small turtles tended to accumulate more $\mathrm{Hg}$ than larger ones was out of scope of the current study. This significant effect was taken into account during the analyses, however. Thus, possible differences among populations regarding mean body size or sex ratio could not account for the strong geographic differences we observed. Moreover, the assays performed in the claws and in the blood provided parallel outcomes: the rivers downstream the south slopes of the Atlas were highly contaminated, exhibiting mean concentrations ten times higher than in other sites. Thus, both long-term integration of claws measurements (i.e. months; Hopkins et al. 2013b) and short-term integration of blood assays (i.e. days-weeks; Hopkins et al. 2013a, b) converged to show that all rivers (and one lake) connected to the catchment basins of the southern slopes of the Atlas were highly contaminated by $\mathrm{Hg}$.

The rivers we sampled in the valleys down the southern slopes of the Atlas also receive the waters from the northern slopes of the Anti-Atlas chain (Fig. 1). In the Anti-Atlas (> 3300 altitude max), mining industries (e.g. Imiter Mine, Jbel Saghro) exploit a peculiar silver ore, $\mathrm{Ag}_{2} \mathrm{HgS}_{2}$, named imiterite (Guillou et al. 1985). This mineral contains appreciable amounts of $\mathrm{Hg}^{2+}$ (Guillou et al. 1985) that can be released in the environment during the extraction of silver. Other mineral deposits precisely situated upstream of the sites we sampled present similarities with the Imiter type deposit; several have been exploited previously or are currently exploited 
(Marcoux and Wadjinny 2005). Overall, in the Anti-Atlas, the extraction of mercuriferous native silver (2 to $30 \mathrm{wt} \% \mathrm{Hg}$; Marcoux andWadjinny 2005) may explain the high level of $\mathrm{Hg}$ contamination of the rivers and lakes situated downstream. The Anti-Atlas region of Morocco is considered as a silver metallogenic province (Marcoux and Wadjinny 2005). Although our sampling strategy was not designed to assess this issue, our data fit well with this scenario. The rivers situated in the valleys that collect the water from the Anti-Atlas were the most contaminated; they all converge to the Ouarzazate artificial lake. Accumulating sediments may favour the fixation and methylation of $\mathrm{Hg}$ where the turtles forage or shelter $(M$. leprosa is a riverbed dweller). One site (11, Oued Drâa; Fig. 1) does not receive waters directly exposed to mine activities, but it is approximately $60 \mathrm{~km}$ downstream of the lake and it is also highly contaminated (the water of Oued Drâa is supplied by the dam).

Further investigations are required to better understand if the high $\mathrm{Hg}$ contamination of the rivers that run between the southern slopes of the Atlas and the northern slopes of the Anti-Atlas is caused by silver deposit exploitations (e.g. using discriminant isotopic signatures of $\mathrm{Hg}$ ). Moreover, other types of mining, industrial and urban activities that can release various trace metals in the environment (e.g. Cd, $\mathrm{Cu}, \mathrm{Pb}$ and $\mathrm{Zn}$ ) should be considered to obtain a more comprehensive view of water contamination by trace metals in Morocco (Sedki et al. 2003; Barkouch and Pineau 2015). Due to complex and often very ancient geological structures, ore deposits and mine exploitations are abundant and very diverse, and they are spread across most of the country (Mouttaqi et al. 2011). Yet, they mostly concentrate in the northern 
slopes of the old formations (> $400 \mathrm{MA}$ ) of the Anti-Atlas (Figs. 1 and 2 in Mouttaqi et al. 2011).

\section{$\underline{\text { Influence of } \mathrm{Hg} \text { concentration on body condition }}$}

We found a negative correlation between $\mathrm{Hg}$ concentration and turtle body condition (Table 2). Although this effect was weak, it was highly significant (Table 2). Perhaps high levels of $\mathrm{Hg}$ contamination perturb the physiology of the turtles as shown in other organisms (Tan et al. 2009). Mean Hg concentrations measured in the dermis of the turtles sampled down the southern slopes of the Atlas were above a critical threshold of $5 \mu \mathrm{g} \mathrm{g}^{-1}$, a value not yet tested/validated in chelonians or in other nonavian reptiles, however (Burger and Gochfeld 2004). Considering RBC concentrations, mean values ranging between 0.6 and $1 \mu \mathrm{g} \mathrm{g}^{-1}$ are however sufficient to perturb the hormonal physiology of turtles (Meyer et al. 2014); our results fall exactly within this range of variation. Alternatively, other environmental factors of the sites sampled may have influenced individual body condition independently from a possible impact of $\mathrm{Hg}$ contamination. For example, turtles sampled in sewers of the large cities may benefit from abundant food resources and permanent water availability. All these sites were situated in catchment basins not exposed to mining activity and thus poorly contaminated by $\mathrm{Hg}$. Experimental and more focused field studies are needed to tease apart these yet fragile hypotheses.

Conclusions 
Our results raise serious concerns about possible chronic exposure to $\mathrm{Hg}$ in the populations that live in vast areas of Morocco (Tan et al. 2009; Green et al. 2010). Consumption of fish taken in the most contaminated rivers, combined with the use of highly contaminated water for irrigation, domestic needs, and for livestock consumption, may contaminate human populations. It would be informative to measure the concentrations of $\mathrm{Hg}$ in the most exposed populations, for example in the hairs. Different Mauremys species are spread over an immense geographic area that extends from southern Europe, North Africa and China. This taxon might be useful to track $\mathrm{Hg}$ exposure risks at a very large scale; museum collection might be used to investigate long-term trends.

\section{Acknowledgments}

The authors thank T. Lechevalier, S. Lecq, and C.L. Michel for assistance during fieldwork. The authors are grateful to C. Churlaud from the Plateforme Analyses Elémentaires of the LIENSs laboratory for her technical support during $\mathrm{Hg}$ analyses. The IUF (Institut Universitaire de France) is acknowledged for its support to PB.

Funding This work was supported by the Hassan II Academy of Sciences and Technics - Morocco (ICGVSA project).

\section{References}

Aschner, M., \& Aschner, J. L. (1990). Mercury neurotoxicity: mechanisms of bloodbrain barrier transport. Neuroscience and Biobehavioral Reviews, 14, 169-176. 
Azimi, S., \& Moghaddam, M. S. (2013). Effect of mercury pollution on the urban environment and human health. Environment and Ecology Research, 1, 12-20.

Barkouch, Y., \& Pineau, A. (2015). Well water contamination at a mining extract zone near Marrakech city in Morocco. Research Review in Biosciences 10, 45-50

Benhamza, M., \& Hammar, Y. (2012). Contamination by mercury of groundwater of the North Numidian zone of Azzaba, North East Algéria. Effect of inorganic mercury contamination of population. International Journal of Environment and Waste Management, 9, 347-357.

Bennasser, L., Fekhaoui, M., Mameli, O., \& Melis, P. (1999). Assessment of the metals contamination of the low Sebou sediments (Morocco). Annali di Chimica, 90, 637644.

Bergeron, C. M., Husak, J. F., Unrine, J. M., Romanek, C. S., \& Hopkins, W. A. (2007). Influence of feeding ecology on blood mercury concentrations in four species of turtles. Environmental Toxicology and Chemistry, 26, 1733-1741.

Bernhoft, R. A. (2011). Mercury toxicity and treatment: a review of the literature. Journal of environmental and public health, 2012, 1-10, doi:10.1155/2012/460508

Bindler, R., Klarqvist, M., Klaminder, J., \& Förster, J. (2004). Does within-bog spatial variability of mercury and lead constrain reconstructions of absolute deposition rates from single peat records? The example of Store Mosse, Sweden. Global Biogeochemical Cycles, 18, GB3020, doi:10.1029/2004GB002270.

Blévin, P., Carravieri, A., Jaeger, A., Chastel, O., Bustamante, P., Cherel, Y. (2013). Wide range of mercury contamination in chicks of Southern Ocean seabirds. PLoS ONE 8, e54508. doi:10.1371/journal.pone.0054508

Boening, D. W. (2000). Ecological effects, transport, and fate of mercury: a general review. Chemosphere, 40, 1335-1351.

Bonnet, X., Lagarde, F., Henen, B. T., Corbin, J., Nagy, K. A., Naulleau, G., Bahloul, K., Chastel, O., Legrand, A., \& Cambag, R. (2001). Sexual dimorphism in steppe tortoises (Testudo horsfieldii): influence of the environment and sexual selection on body shape and mobility. Biological Journal of the Linnean Society, 72, 357372. 
Bonnet, X., Delmas, V., El-Mouden, H., Slimani, T., Sterijovski, B., \& Kuchling, G. (2010). Is sexual body shape dimorphism consistent in aquatic and terrestrial chelonians?. Zoology, 113, 213-220.

Bonnet, X., El Hassani, M. S., Lecq, S., Michel, C. L., El Mouden, E. H., Michaud, B., \& Slimani, T. (2016). Blood mixtures: impact of puncture site on blood parameters. Journal of Comparative Physiology B, 186, 787-800.

Chahid, A., Hilali, M., Benlhachimi, A., \& Bouzid, T. (2014). Contents of cadmium, mercury and lead in fish from the Atlantic sea (Morocco) determined by atomic absorption spectrometry. Food Chemistry, 147, 357-360.

Driscoll, C. T., Mason, R. P., Chan, H. M., Jacob, D. J., \& Pirrone, N. (2013). Mercury as a global pollutant: sources, pathways, and effects. Environmental Science \& Technology, 47(10), 4967-4983.

Elhamri, H., Idrissi, L., Coquery, M., Azemard, S., El Abidi, A., Benlemlih, M., Saghi, M., Cubadda, F. (2007). Hair mercury levels in relation to fish consumption in a community of the Moroccan Mediterranean coast. Food Additives and Contaminants, 24, 1236-1246.

Fritz, U., Barata, M., Busack, S. D., Fritzsch, G., \& Castilho, R. (2006). Impact of mountain chains, sea straits and peripheral populations on genetic and taxonomic structure of a freshwater turtle, Mauremys leprosa (Reptilia, Testudines, Geoemydidae). Zoologica Scripta, 35, 97-108.

Green A.D., Buhlmann K.A., Hagen C., Romanek C. and Gibbons J.W. (2010). Mercury contamination in turtles and implications for human health. Journal of Environmental Health 72, 14-22.

Guillou, J. J., Monthel, J., Picot, P., Pillard, F., Protas, J., \& Samama, J. C. (1985). L'imitérite, $\mathrm{Ag}_{2} \mathrm{HgS}_{2}$, nouvelle espèce minérale; propriétés et structure cristalline. Bulletin de minéralogie, 108, 457-464.

Hopkins B.C., Hepner M.J., Hopkins W.A. (2013a). Non-destructive techniques for biomonitoring of spatial, temporal, and demographic patterns of mercury bioaccumulation and maternal transfer in turtles. Environmental Pollution 77, 164170. 
Hopkins W.A., Bodinof C., Budischlak S. and Perkins Christopher (2013b).

Nondestructive indices of mercury exposure in three species of turtles occupying different trophic niches downstream from a former chloralkali facility.

Ecotoxicology 22, 22-32.

Jernelöv, A., \&Lann, H. (1971). Mercury accumulation in food chains. Oikos, 403-406.

Maanan, M. (2007). Biomonitoring of heavy metals using Mytilus galloprovincialis in Safi coastal waters, Morocco. Environmental Toxicology, 22, 525-531.

Marcoux, É., \& Wadjinny, A. (2005). The Ag Hg Zgounder ore deposit (Jebel Siroua, Anti-Atlas, Morocco): a Neoproterozoic epithermal mineralization of the Imiter type. Comptes Rendus Geoscience, 337, 1439-1446.

Mason, R. P., Fitzgerald, W. F., \& Morel, F. M. (1994). The biogeochemical cycling of elemental mercury: anthropogenic influences. Geochimica et Cosmochimica Acta, 58, 3191-3198.

Mason, R. P., \& Sheu, G. R. (2002). Role of the ocean in the global mercury cycle. Global biogeochemical cycles, 16, 1-14.

Meek, R. (1987). Aspects of the population ecology of Mauremys caspica in North West Africa. Herpetological journal, 1, 130-136.

Meyer E., Eagles-Smith C.A., Sparling D. and Blumenshine S. (2014). Mercury exposure associated with altered plasma thyroid hormones in the declining western pond turtle (Emys marmorata) from California Mountain Streams. Environmental Science and Technology 48, 2989-2996.

Meyers-Schöne, L., Shugart, L. R., Walton, B. T., \& Beauchamp, J. J. (1993). Comparison of two freshwater turtle species as monitors of radionuclide and chemical contamination: DNA damage and residue analysis. Environmental Toxicology and Chemistry, 12, 1487-1496.

Miller, E. K., Vanarsdale, A., Keeler, G. J., Chalmers, A., Poissant, L., Kamman, N. C., \& Brulotte, R. (2005). Estimation and mapping of wet and dry mercury deposition across northeastern North America. Ecotoxicology, 14, 53-70.

Morel F. M. M., Kraepiel A. N. L. and Amyot M. (1998). The Chemical cycle and bioaccumulation of mercury. Annual Review of Ecology and Systematics 29, 543 566. 
Mokhtari, N. Mrabet R., Lebailly P., Bock L. (2013). Spatialisation des bioclimats, de l'aridité et des étages de végétation du Maroc. Revue Marocaine des Sciences Agronomiques et Vétérinaires, 2, 50-66.

Mouttaqi, A., Rjimati, E., Maacha, A., Michard, A., Soulaimani, A., \& Ibouh, H. (2011). Les principales mines du Maroc. Ministère de l'énergie, des mines, de l'eau et de l'environnement direction du développement minier, 9 (375 p).

Pacyna, E. G., Pacyna, J. M., Sundseth, K., Munthe, J., Kindbom, K., Wilson, S., Steenhuisen F. \& Maxson, P. (2010). Global emission of mercury to the atmosphere from anthropogenic sources in 2005 and projections to 2020. Atmospheric Environment, 44, 2487-2499.

Pirrone, N., Costa, P., Pacyna, J. M., \& Ferrara, R. (2001). Mercury emissions to the atmosphere from natural and anthropogenic sources in the Mediterranean region. Atmospheric Environment, 35, 2997-3006.

Rutter, A. P., Schauer, J. J., Lough, G. C., Snyder, D. C., Kolb, C. J., Von Klooster, S., Rudolf, T., Manolopoulosa, H. \& Olson, M. L. (2008). A comparison of speciated atmospheric mercury at an urban center and an upwind rural location. Journal of Environmental Monitoring, 102008, 102-108.

Schneider, L., Maher, W., Green, A., \& Vogt, R. C. (2013). Mercury contamination in reptiles: an emerging problem with consequences for wild life and human health. Mercury: Sources, Applications and Health Impacts. Nova Science Publishers, Inc., Hauppauge, New York, USA, 173-232.

Schneider, L., Eggins, S., Maher, W., Vogt, R. C., Krikowa, F., Kinsley, L., Eggibns S.M., \& Da Silveira, R. (2015). An evaluation of the use of reptile dermal scutes as a non-invasive method to monitor mercury concentrations in the environment. Chemosphere, 119, 163-170.

Sedki, A., Lekouch, N., Gamon, S., \& Pineau, A. (2003). Toxic and essential trace metals in muscle, liver and kidney of bovines from a polluted area of Morocco. Science of the Total Environment, 317, 201-205.

Selin, N. E. (2009). Global biogeochemical cycling of mercury: a review. Annual Review of Environment and Resources, 34, 43. 
Selin, N. E., \& Jacob, D. J. (2008). Seasonal and spatial patterns of mercury wet deposition in the United States: Constraints on the contribution from North American anthropogenic sources. Atmospheric Environment, 42, 5193-5204.

Tan, S. W., Meiller, J. C., \& Mahaffey, K. R. (2009). The endocrine effects of mercury in humans and wildlife. Critical reviews in toxicology, 39, 228-269.

Turnquist, M. A., Driscoll, C. T., Schulz, K. L., \& Schlaepfer, M. A. (2011). Mercury concentrations in snapping turtles (Chelydra serpentina) correlate with environmental and landscape characteristics. Ecotoxicology, 20, 1599-1608.

Wang, Q., Kim, D., Dionysiou, D. D., Sorial, G. A., \& Timberlake, D. (2004). Sources and remediation for mercury contamination in aquatic systems - a literature review. Environmental Pollution, 131, 323-336.

Wayland, M., Smits, J. J., Gilchrist, H. G., Marchant, T., \& Keating, J. (2003). Biomarker responses in nesting, common eiders in the Canadian arctic in relation to tissue cadmium, mercury and selenium concentrations. Ecotoxicology, 12, 225237.

Wei, B., \& Yang, L. (2010). A review of heavy metal contaminations in urban soils, urban road dusts and agricultural soils from China. Microchemical Journal, 94, 99-107. 
Table 1. Broad characteristics of the 13 study sites sampled. The name of each river (+ one lake) and of the nearest city (in brackets) are provided. Site number (1 - 13) and locations are also indicated in the Figure 1. Climatic characteristics were derived from Mokhtari et al. (2013). Further hydraulic information regarding each site is provided column 4 and 5 . The last column $(\mathrm{N})$ provides the number of turtle sampled per site.

\begin{tabular}{|c|c|c|c|c|c|c|}
\hline River (study site) & City & Coordinates & Climate & River type & Water & Number \\
\hline Sebou (1) & Fes & $34^{\circ} 02^{\prime} 16^{\prime \prime} \mathrm{N} 5^{\circ} 00^{\prime} 12^{\prime \prime} \mathrm{W}$ & Fresh to temperate semi-arid & Continuous & Sewers & 11 \\
\hline Sebou (2) & Meknes & $33^{\circ} 84^{\prime} 37^{\prime \prime} \mathrm{N} 5^{\circ} 51^{\prime} 06^{\prime \prime} \mathrm{W}$ & Temperate to hot semi-arid & Continuous & Sewers & 7 \\
\hline Sebou (3) & Moulay Driss & $34^{\circ} 05^{\prime} 18^{\prime \prime} \mathrm{N} 5^{\circ} 52^{\prime} 83^{\prime \prime} \mathrm{W}$ & Fresh to temperate semi-arid & Continuous & High flow & 10 \\
\hline Ouaoumana (4) & Ouaoumana & $32^{\circ} 54^{\prime} 56^{\prime \prime} \mathrm{N} 5^{\circ} 49^{\prime} 51^{\prime \prime} \mathrm{W}$ & Cold to very cold semi-arid & Continuous & From foothills & 13 \\
\hline Zat (5) & Ait Ourir & $31^{\circ} 55^{\prime} 99^{\prime \prime} \mathrm{N} 7^{\circ} 67^{\prime} 70^{\prime \prime} \mathrm{W}$ & Fresh to temperate arid & Continuous & From foothills & 12 \\
\hline Tensift (6) & Marrakech & $31^{\circ} 37^{\prime} 40^{\prime \prime} \mathrm{N} 7^{\circ} 59^{\prime} 05^{\prime \prime} \mathrm{W}$ & Temperate to hot arid & Discontinuous & Sewers & 44 \\
\hline Moulouya (7) & Zaïda & $32^{\circ} 51^{\prime} 42^{\prime \prime} \mathrm{N} 4^{\circ} 54^{\prime} 09^{\prime \prime} \mathrm{W}$ & Cold to fresh semi-arid & Discontinuous & Sewers & 19 \\
\hline $\mathrm{Ziz}(8)$ & Meski & $31^{\circ} 51^{\prime} 15^{\prime \prime} \mathrm{N} 4^{\circ} 16^{\prime} 49^{\prime \prime} \mathrm{W}$ & Sub-Saharan & Discontinuous & Slow flow & 28 \\
\hline M'Gouna (9) & Kelaat M'Goun & $31^{\circ} 32^{\prime} 24^{\prime \prime} \mathrm{N} 6^{\circ} 20^{\prime} 21^{\prime \prime} \mathrm{W}$ & Sub-Saharan & Permanent & High flow & 13 \\
\hline Dades (10) & Skoura & $31^{\circ} 01^{\prime} 18^{\prime \prime} \mathrm{N} 6^{\circ} 28^{\prime} 46^{\prime \prime} \mathrm{W}$ & Sub-Saharan & Permanent & High flow & 20 \\
\hline Draa (11) & Agdez & $30^{\circ} 40^{\prime} 31^{\prime \prime} \mathrm{N} 6^{\circ} 24^{\prime} 25^{\prime \prime} \mathrm{W}$ & Sub-Saharan & Continuous & Varying flow & 15 \\
\hline Lake (12) & Ouarzazate & $30^{\circ} 91^{\prime} 73^{\prime \prime} \mathrm{N} 6^{\circ} 76^{\prime} 39^{\prime \prime} \mathrm{W}$ & Cold to fresh per-arid & Permanent & Lake & 8 \\
\hline Iriri (13) & Amerzagan & $30^{\circ} 39^{\prime} 24^{\prime \prime} \mathrm{N} 7^{\circ} 42^{\prime} 93^{\prime \prime} \mathrm{W}$ & Sub-Saharan & Temporary & From a lake & 11 \\
\hline Total & & & & & & 211 \\
\hline
\end{tabular}


Table 2. Results of a backward stepwise regression analysis to examine the influence of $\mathrm{Hg}$ contamination on the body condition of the turtles. Log-body mass was implemented as the dependent variable, log-body size (SSL), and $\mathrm{Hg}$ concentrations measured in the claw were the explanatory variables. The final model retained both explanatory variables $\left(\mathrm{r}=0.99\right.$, adjusted- $\left.\mathrm{R}^{2}=0.98, \mathrm{~F}_{2,206}=5256.37, \mathrm{P}<0.001\right) . b^{*}$ stands for standardized regression coefficients, $b$ for regression coefficients, and $S E$ stands for standard error

\begin{tabular}{lcccccc}
\hline & $\mathbf{b}^{*}$ & $\mathbf{b}^{*}-\mathrm{SE}$ & $\mathbf{b}$ & $\mathbf{b}-\mathrm{SE}$ & $\mathbf{t}(\mathbf{2 0 6})$ & $\mathbf{P}$ \\
\hline Intercept & & & -3.418 & 0.062 & -55.210 & $<0.0001$ \\
Log Hg & -0.040 & 0.010 & -0.028 & 0.007 & -3.941 & $<0.0010$ \\
Log SSL & 0.978 & 0.010 & 2.805 & 0.029 & 96.584 & $<0.0001$ \\
\hline
\end{tabular}


Table 3 Main results of a GLM analysis to explore the effect of site (13 aquatic sites sampled), body mass, and sex (194 individuals sexed) on $\mathrm{Hg}$ concentrations measured in the claws of Mediterranean turtles in Morocco (A). The analysis was performed again without including sex as a factor (B), increasing the sample size to 209 ( $\mathrm{Hg}$ was assayed in 211 turtles but body mass was missing in two individuals) enabling us to include small unsexed individuals (15 juveniles).

\begin{tabular}{lccc}
\hline \multicolumn{1}{c}{ Source } & Df & Wald Stat & P \\
\hline A - & & & \\
Intercept & 1 & 5.682 & 0.0171 \\
$\quad$ Site & 12 & 195.670 & $<0.001$ \\
Body mass & 1 & 4.120 & 0.0424 \\
$\quad$ Sex & 2 & 3.352 & 0.0671 \\
\hline B - & & & \\
Intercept & 1 & 10.073 & 0.0015 \\
$\quad$ Site & 12 & 220.443 & $<0.001$ \\
Body mass & 1 & 8.284 & 0.0034 \\
\hline
\end{tabular}


Table 4: Parameter estimates using GLM analysis to explore the effect of geographic site on $\mathrm{Hg}$ concentrations measured in the claws of freshwater turtles; body mass was implemented as a covariate. Site number is indicated in brackets (see Figure 1 for locations). Although 13 sites were sampled, one (Zaïda, site \#6) was retained as a reference and thus results are provided for 12 sites.

\begin{tabular}{lcccccr}
\hline Effect & Estimation & SE & Up-95\% CI & Lo-95\% CI & Wald stat & \multicolumn{1}{c}{$P$} \\
\hline Sebou (1) & -1.248 & 0.560 & -0.347 & -2.149 & 7.368 & 0.007 \\
Sebou (2) & -1.693 & 0.493 & -0.726 & -2.659 & 11.780 & $<0.001$ \\
Sebou (3) & -0.023 & 0.291 & 0.548 & -0.594 & 0.006 & 0.936 \\
Ouaoumana (4) & 0.092 & 0.202 & 0.489 & -0.303 & 0.207 & 0.649 \\
Zat (5) & -0.967 & 0.325 & -0.330 & -1.604 & 8.861 & 0.003 \\
Tensift (7) & -1.665 & 0.263 & -1.150 & -2.180 & 40.180 & $<0.001$ \\
Ziz (8) & -0.385 & 0.177 & -0.039 & -0.732 & 4.748 & 0.029 \\
M'goun (9) & 0.676 & 0.156 & 0.982 & 0.370 & 18.777 & $<0.001$ \\
Dades (10) & 1.325 & 0.111 & 1.542 & 1.108 & 142.806 & $<0.001$ \\
Draa (11) & 1.092 & 0.127 & 1.340 & 0.843 & 74.163 & $<0.001$ \\
Lake (12) & 1.117 & 0.155 & 1.421 & 0.813 & 51.852 & $<0.001$ \\
Iriri (13) & 1.638 & 0.120 & 1.873 & 1.402 & 185.810 & $<0.001$ \\
\hline
\end{tabular}


Table 5. Main results of a GLM analysis to test the effect of the assignment of 13 aquatic sites in three main geographic areas (see figure 1 for details), with body mass included as a covariate, on $\mathrm{Hg}$ concentrations measured in the claws of freshwater turtles in Morocco.

\begin{tabular}{cccc}
\hline Source & Df & Wald Stat & $\mathbf{P}$ \\
\hline Intercept & 1 & 15.598 & $<0.001$ \\
Geographic area & 2 & 200.418 & $<0.001$ \\
Body mass & 1 & 7.859 & 0.005 \\
\hline
\end{tabular}


Figure 1. Location of the 13 aquatic sites sampled along a wide geographical gradient in Morocco. Each site is referred to a number for simplicity, the name of the river, and the name of the nearest city in brackets. The rivers $1-6$ situated north to the high Atlas and middle Atlas chains run toward the west. The river 7 situated between these two chains runs toward the east. The rivers 7 - 13 (+ one lake) situated south of the High Atlas and north to the Anti-Atlas (except \# 8) run to the south. 1) Sebou (Fes), 2) Sebou (Moulay Driss), 3) Sebou ( Meknes), 4) Ouaoumana (Ouaoumana), 5) Zat (Ait Ourir), 6), Tensift (Marrakech), 7) Moulouya (Zaïda), 8) Ziz (Meski), 9) M'Goun (Kelaat M'Gouna), 10) Dades (Skoura), 11) Draa (Agdez), 12) Lake (Ouarzazate), 13) Iriri (Amerzagan). Map obtained from Ginkgomaps Projet, http://www.ginkgomaps.com/cartes_maroc.html

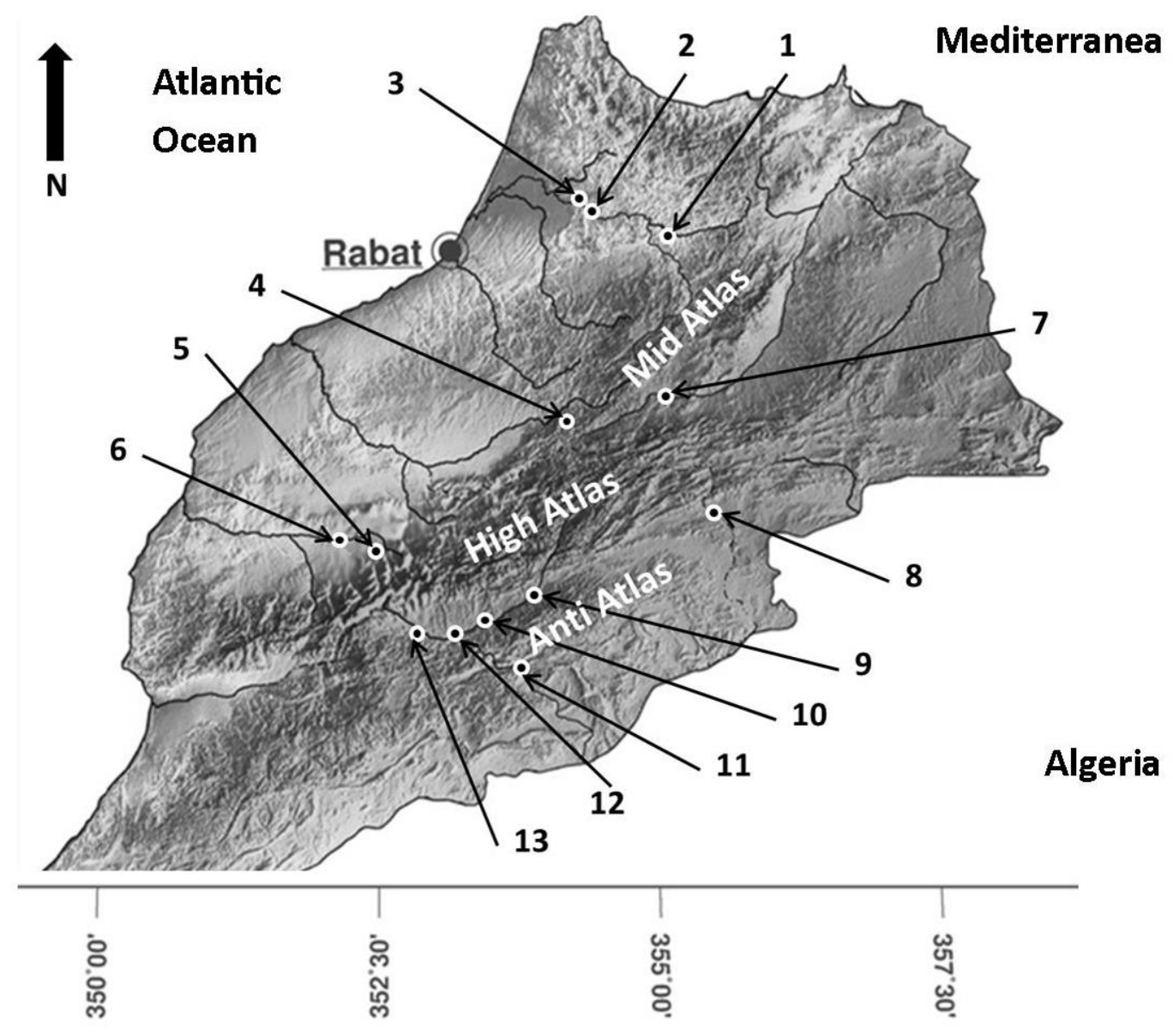


Figure 2. Relationship between $\mathrm{Hg}$ concentrations assayed in the claws versus blood in 34 Mediterranean turtles.

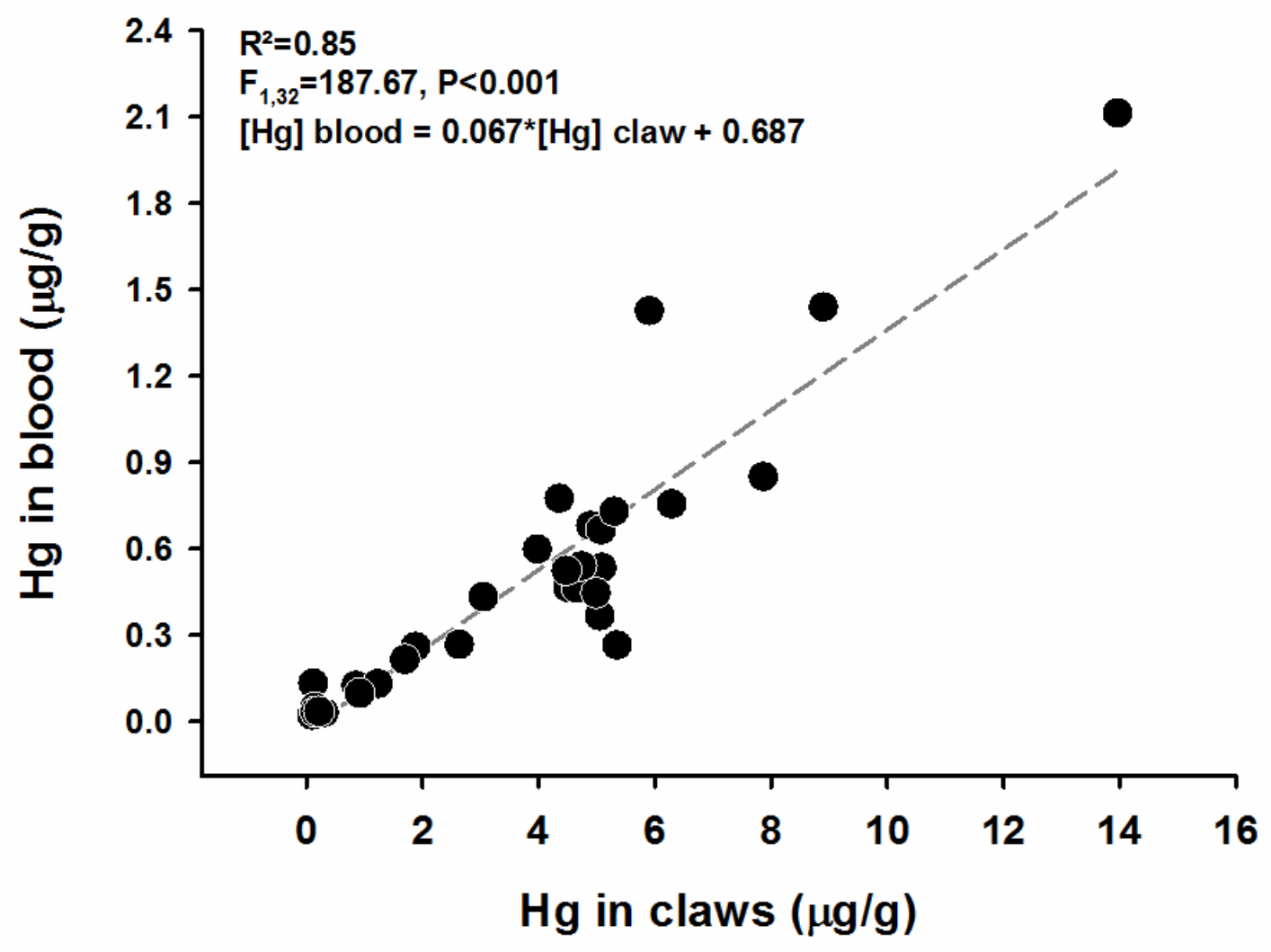


Figure 3. Relationship between body mass and $\mathrm{Hg}$ concentration measured in the claw (a) and in the red blood cells (RBC) (b) of Mediterranean turtles. The parameters of the equation were respectively for the claw and for the RBC: $R^{2}=-0.110, F_{1,207}=$ 25.710, log $[\mathrm{Hg}]$ claw $=-0.33 \log . \mathrm{BM}+1.09 ; \mathrm{R}^{2}=-0.564, \mathrm{~F}_{1,56}=72.413, \log [\mathrm{Hg}] \mathrm{RBC}$ $=-0.75$ log. $\mathrm{BM}+2.56$. White, grey and black circles denote respectively sites from the north (sites 1-6), east (sites 7 and 8) and south catchments basins (sites 9-13); see text for further analyses and details
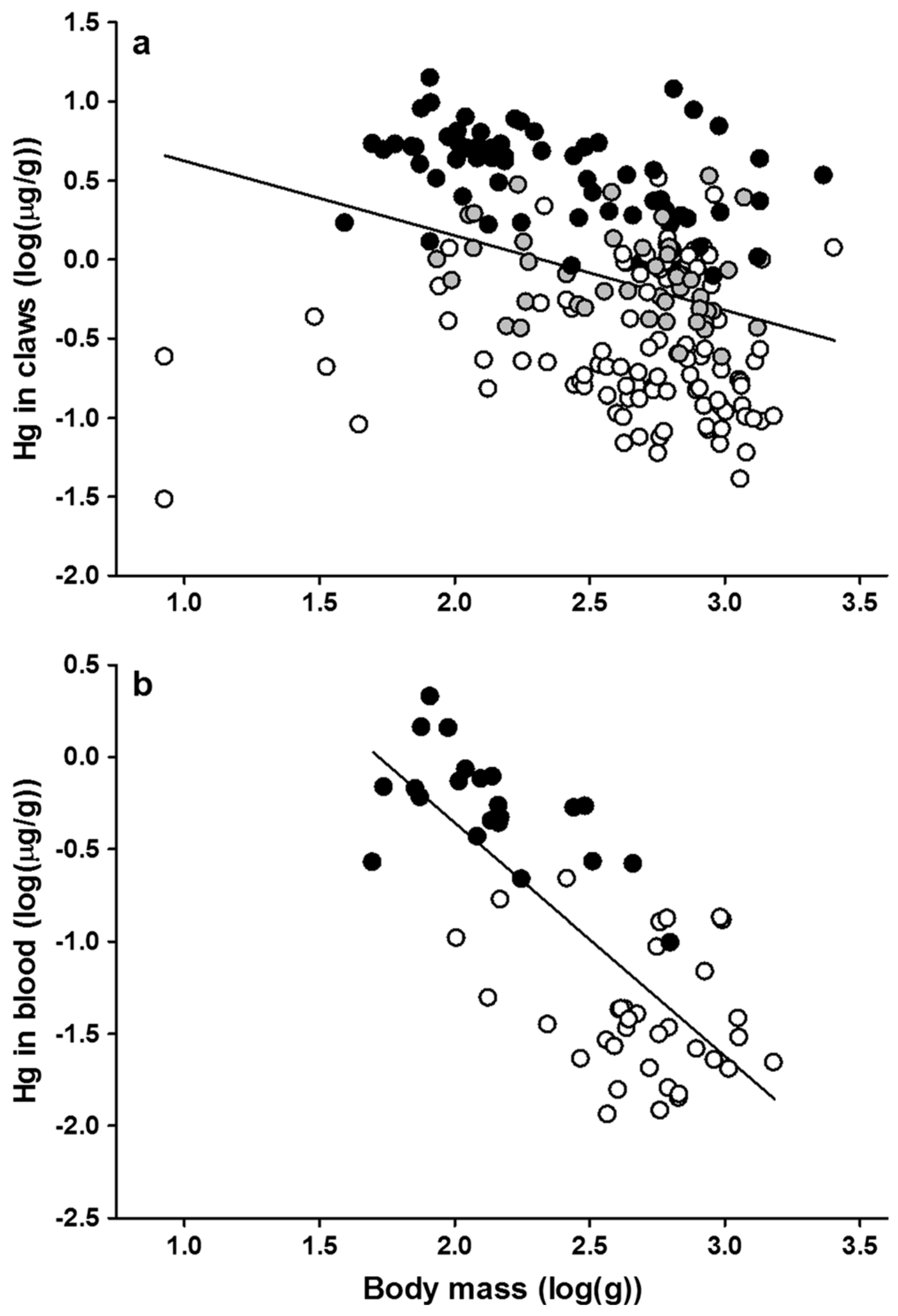
Figure 4. Mean Hg concentrations $( \pm \mathrm{SD}$ ) measured in the claws of Mediterranean turtles sampled in 13 aquatic sites (site number in X-axis as in Fig. 1). Details and location of each site are provided in Table 1. White, grey and black bars denote respectively sites from the north (siteS 1-6), east (sites 7 and 8) and south catchments basins (sites 9-13). The top graph (a) provides uncorrected mean values; the lower graph $(b)$ provides mean values scaled by body mass
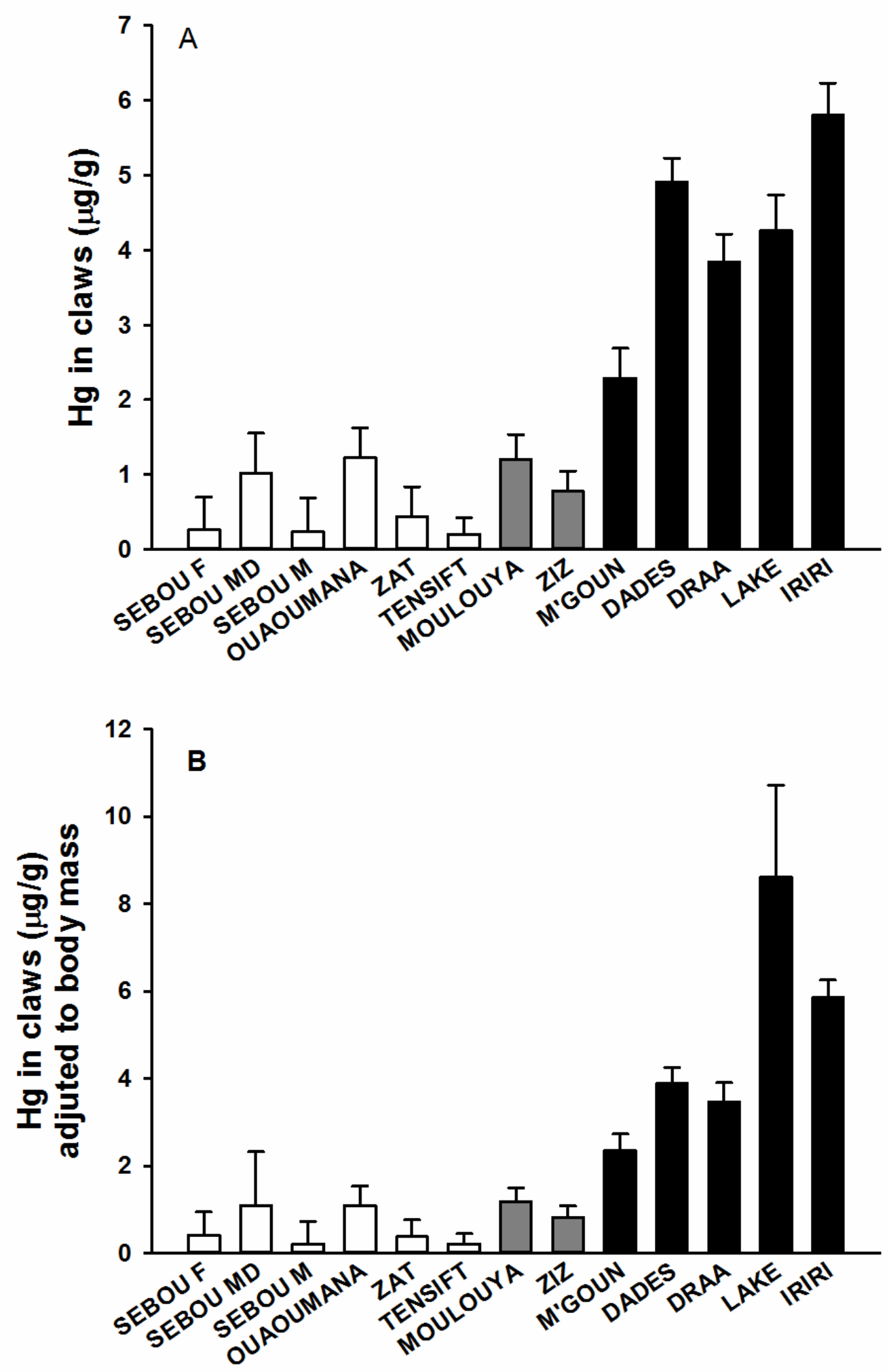